\title{
Terminological challenges in the translation of science documentaries: a case-study ${ }^{1}$
}

\section{Anna Matamala}

Address: Dr. Anna Matamala

Universitat Autònoma de Barcelona

Facultat de Traducció i d'Interpretació

Edifici K

08193 Bellaterra (Cerdanyola del Vallès)

E-mail: anna.matamala@uab.cat

Phone: +34935811646

Fax: +34 935812762

\begin{abstract}
This article aims to describe some of the main terminological problems audiovisual translators have to face when dealing with the translation of science documentaries, specifically in the English-Catalan combination. The first section of the article presents some theoretical concepts which underlie this research and which are taken, for the most part, from Cabré's Communicative Theory of Terminology. Then, specific terminological problems audiovisual translators have to solve are described using the data provided by a corpus of four science documentaries lasting approximately 50 minutes each. These challenges include identifying a term, understanding a term, finding the right equivalent, dealing with the absence of an adequate equivalent, solving denominative variations, choosing between in vivo and in vitro terminology, and overcoming mistranscriptions.
\end{abstract}

Key words: audiovisual translation, terminology, documentaries, science popularisation

\footnotetext{
${ }^{1}$ This research is part of the Catalan Government Consolidated Research Group scheme with the reference
} 


\section{Introduction}

Although the relationship between terminology and translation has been widely discussed (Arntz 1993, Cabré 1998, 2002, 2004, Cabré et alii 2002, Gouadec \& Toudic 2003, Rogers 2006, Sager 1992, Velasquez 2002, among others), the specificities of terminology in audiovisual translation (AVT) have been generally neglected both in terminology studies and AVT studies. The few references that do appear in the bibliography generally refer to documentaries, a genre which has been relegated to second place in AVT.

This article aims to describe some of the main terminological problems translators have to face when dealing with the translation of documentaries, specifically in the English-Catalan combination. The first section tackles theoretical issues: the main contributions to the field are reviewed and theoretical concepts which underlie this research, taken for the most part from Cabré's Communicative Theory of Terminology, are presented. Then, specific terminological problems audiovisual translators have to solve are described using the data provided by a corpus of four randomly selected science documentaries. Needless to say that, despite my focus within this paper on non-fiction, I am all too aware of the existence of terminological units in some fiction products (Bestué 2005, Lozano 2005, Lozano \& Matamala 2009).

\section{Documentaries and terminology in AVT}

The translation of documentaries has been analysed by various authors in AVT studies, although it has not attracted as much attention as fiction. Ferreira (2002), Franco (2000a, 2000b, 2001a, 2001b), Franco, Matamala and Orero (forthcoming), Hoorickx-Raucq (2004), Kaufmann (2004, 2008), Matamala (2009a, 2009b), Orero (2004, 2005, 2006, 2007), Remael $(1995,2007)$ and Taylor $(2002)$ are some of the main contributors to the field and have approached it either through the genre - articles on documentaries and non-fiction in AVTor through the transfer mode used — articles on voice-over mainly but also on subtitling.

Regarding terminology and documentaries, Mir (1999) and Mateu (2005) adopt an industry professional's approach and consider terminology to be a challenging issue when translating documentaries, whilst Matamala (2009a, 2009b) makes a step forward and presents a list of difficulties. On a different note, Espasa (2004:193) relates terminology to the audience for which the translation is designed and provides examples to prove that target audiences determine translators' choices.

2009SGR700. 
Although the number of publications on this issue is not extensive, the relationship between documentaries and terminology could open many research avenues due to the specificities of terms in audiovisual products generally targeted at a wide audience.

\section{Science documentaries, specialised discourse and terminology}

Documentaries are not a single category but encompass various modalities, as pointed out by Renov (1993:21), Rabiger (2004:54) and Nichols (2001), who have proposed different categorisations and have demonstrated that boundaries are overlapping. This paper will deal with science documentaries, a broad category which resorts to various narrative and dramatic techniques to engage the spectator with various science related topics (León 1999:64, Faceira 2002). Science documentaries popularise many scientific issues, using in general somewhat specialised speakers located in carefully chosen environments or contexts, and address various types of audiences. These four elements (topics, speakers, contexts and audiences) open a wide array of possibilities which are given a concrete shape in the audiovisual product: an off-screen narrator addressing a lay audience with a planned discourse, a scientist addressing the camera in a semi-planned situation, a specialist talking spontaneously to a colleague, or a lecturer giving a course on a specialised topic to advanced learners are just a few examples. Despite their varied nature, the finished films will always aim to popularise a specialised topic and, most importantly, to entertain the audience.

In spite of the differences within this broad category, science documentaries can be considered specialised texts. The language of specialised texts and audiovisual products that deal with a specialised topic differs because scientific processes are explained differently according to the presumed previous knowledge of the target audience (León 1999:104). However, science popularisation can be considered an instance of specialised discourse:

Terminological units have to be studied in the framework of specialised communication, which is characterised by such external conditions as sender, recipient and medium of communication, by conditions of information treatment, such as a precise categorisation determined externally by the conceptual structure, fixation and validated by the expert community, by specific and contextualised treatment of the topic, and, finally, by conditions which restrict the function and objectives of this communication. [...] This broad communicative framework harbours a number of communicative scenarios with the sole condition that they transfer specialised knowledge. They cover, for 
instance, communication among specialists, between specialists and semispecialists or technicians, between specialists and learners, as well as popularisation of science and technology. (Cabré 2003:188)

Therefore, being specialised texts, science documentaries contain terminological units (TU) as "[o]ral or written discourse by specialists addressed directly, or through some form of mediation, to specific groups of recipients constitutes the material in which we can observe terminological units" (Cabré 2003:189).

Terms can be analysed within different theoretical frameworks: traditional approaches such as the Vienna school (Wüster 1979, Felber 1984) or the Russian school (see the contributions by Danilenko or Lotte, among others, compiled by Cabré et alii 2001), and more innovative approaches such as the socioterminology (Gaudin 1993), the sociocognitive terminology theory (Temmerman 2000) or the Communicative Theory of Terminology (Cabré 2003), among others. This last theoretical framework - namely the Communicative Theory of Terminology — has been chosen for this article. Hence, following Cabré's proposal, terminology is considered interdisciplinary by nature, but terms are approached through the "door of languages", i.e. from the viewpoint of a theory of natural language (Cabré 1999:70).

According to Cabré, TU are polyhedric, being at the same time units of knowledge, units of language and units of communication. From a linguistic perspective - that is, considering them units of language - TU are lexical units: they have a lexical and syntactic structure and they exploit all the devices of word formation. Formally, they may coincide with units belonging to general discourse, and, as far as word classes are concerned, they occur as nouns, verbs, adjectives, adverbs or nominal, verbal, adjectival or adverbial structures. From a semantic point of view, they belong to one of the following categories: entities, events, properties, or relations. Their meaning is discreet within a specialised subject and is extracted from the set of information of a lexical unit. Terminological meaning is activated by the pragmatic features of the discourse, and contrary to what traditional approaches to terminology propose, variation - that is, polysemy and synonymy — is present (Freixa 2005, 2006). TU are to be found in both oral and written productions produced in the framework of specialised communication. The problems posed by these units to translators are various and will be tackled next.

\section{Terminological problems in translation}


The relationship between terminology and translation has always been a close one. From a theoretical point of view, the theory of terminology can make translators aware of many concepts such as the very notion of "a term" or the idea of variation, which allows them to identify terms and deal with equivalent denominations. From a practical perspective, translators often venture into the field of terminography: they need to carry out ad hoc searches and they might even need to create terminological neologisms (Célestin, Godbout \& Vachon-L’Hereux 1984, Cabré 1992, Temmermann 2000).

Regarding the main terminological challenges faced by translators, Cabré (1999:216217) proposes the following list:

Concerning the terminology of the source language:

- knowing or specifying the meaning of a TU from the source text;

- confirming its specialised nature;

- knowing its denominative alternatives and the conditions in which they are used in texts.

Concerning the terminology of the target language:

- knowing if there is an equivalent TU in the target language;

- if so, knowing what resources can or must be used in order to adapt or create a reasonable denomination and how to indicate that it is a neologism;

- knowing the most adequate equivalent unit taking into account the topic and the approach;

- knowing if a term has specific or restrictive grammatical usages;

- knowing the prototypical combination of terms;

- knowing the usual phraseology in the field;

- knowing denominative alternatives for a single concept and their pragmatic conditions

- making sure that the selected denominative unit corresponds exactly to the concept, etc.

Focusing on documentaries, Matamala (2009a) outlines a list of problem categories which will be used in this article as a starting point for the case-analysis. These categories include: identifying terms, understanding terms, finding an equivalent, dealing with variation, choosing between in vivo and in vitro terminology, overcoming the absence of an equivalent, dealing with ambiguity and handling obscure equivalents for lay audiences.

\section{Terminological challenges in the translation of documentaries: a case-study}


The data used for the case-study has been obtained from four science documentaries each lasting about 50 minutes: Crater of Death (BBC-Horizon, 1997), Hackers (Channel 4, 2001), Red Storm (National Geographic, 2000), and The Quest: Swimming With Giants (Animal Planet, 2001). They deal with different topics - the Cretaceous-Tertiary mass extinction, hackers' activities, dust storms, and humpback whales - and have been randomly selected based on the availability of material (scripts and broadcast versions). Terminology from the source text has been extracted manually and equivalents used in the revoiced version in Catalan have been identified. This analysis has allowed the detection of the main difficulties of this audiovisual product from a terminological point of view. The transfer modes used are voice-over in interviews (i.e. a target language version which is heard on top of the original speech, the volume of which is lowered) and off-screen dubbing in narrations (i.e. an offscreen narration which totally substitutes the original language soundtrack) (Franco, Matamala \& Orero, forthcoming).

It should be noted that translators working for the Catalan television TVC are given an audiovisual file plus a written script if available, and they deliver a written translation which is then checked by a linguist and recorded in a dubbing studio by a professional voice talent. In this study both the original script given to the translator as well as the written translation, which often includes notes addressed to the linguist, have been consulted. These notes have proved an invaluable source of information as they often explain the reasons behind certain terminological choices.

From the data referred to previously, one can observe that some terms have posed the following difficulties:

\subsection{Identifying a term}

Identifying a term can sometimes be difficult, especially when the form coincides with that of a general language word. This is what happened with the word sequence in example (1), from Crater of Death:

- Original version: We're down to about three hundred metres below the surface, and we're into rubbly rock that's composed of little bits of broken up rock that were blasted out of the crater. The drilling continued to a total depth of about five hundred metres and we never got out of this sequence.

- Catalan version: Quan vam baixar a uns tres-cents metres sota la superficie, vam trobar rocalla formada per l'acumulació de petits fragments de pedra que havien sortit disparats del cràter. Vam 
continuar perforant fins a uns cinc-cents metres i no sortiem d'aquesta seqüència. [When we were down about three hundred metres below the surface, we found rubbly rock composed of little bits of rock that were blasted out of the crater. The drilling continued to a total depth of about five hundred metres and we never got out of this sequence.]

The term sequence in geology refers to a sequence of geological events, processes, or rocks, arranged in chronological order. It is evident that the translator found this term problematic because in a footnote addressed to the linguists one can read the source where the equivalent and its specific definition in the field of geology was found. Although this term was ultimately translated successfully, it shows how words acquire specialised meaning in context, as stated in the above theoretical framework.

\subsection{Understanding a term}

The following paragraph was especially problematic to the translator and was also found in Crater of Death (see 2).

(2)

- Original version: The Fern Spike is that brief period of time represented by about ten centimetres of rock, a layer about this thick, that occurs just above the iridium-bearing horizon. And in that fern spike we find about one hundred percent of the flora, ninety to one hundred percent is made up of fern spores. And those spores are what we believe to be evidence of a flora that was recovering from the disaster of the impact. Basically colonising a devastated landscape. // Speaker 2: The fern spike, I think is an incredibly important observation. Without it, then I think we're still sort of stabbing in the dark. But in North America that fern spike is much bigger than any other location in the world.

- Catalan version: Hi ha un periode de temps breu representat per deu centímetres de roca, una capa d'aquest gruix que es troba just per sobre de l'horitzó irídic. En aquesta capa hi trobem gairebé el cent per cent de la flora, i entre un noranta $i$ un cent per cent d'aquesta flora correspon a espores de falgueres. Creiem que aquestes espores són una mostra de la flora que s'estava recuperant del desastre provocat per l'impacte. Podriem dir que estaven colonitzant un paisatge devastat.// Aquesta capa de falgueres va ser una troballa fonamental. Si no, encara aniriem a les palpentes. A l'Amèrica del Nord aquesta capa és molt més important que a qualsevol altre punt del món. [There is a brief period of time represented by ten centimetres of rock, a layer about this thick, that occurs just above the iridium-bearing horizon. In that layer we find about one hundred percent of the flora, and between ninety to one hundred percent of this flora is made up of fern spores. We believe these spores are evidence of flora that was recovering from the disaster caused by the impact. We could say they were colonising a devastated landscape.// This fern layer was a 
key finding. Without it, we would still be stabbing in the dark. In North American this layer is more important than in any other location in the world.]

Fern spike refers to the occurrence of abundant fern spores in the fossil record, usually after an extinction event. Thanks to a footnote in the written translation, it is also evident that the translator found it difficult to understand this sentence and decided to adapt its meaning. In its first occurrence the translator deletes the term and rephrases the sentence ("The fern spike is that brief period of time represented..." $>$ [There is a brief period of time represented by...]); in the second and fourth occurrences the term is replaced by a more general term ("And in that fern spike"> [And in that layer]; "fern spike"> [layer]); and in the third one, an equivalent is proposed ("fern spike"> [fern layer]). This shows that the translator did not find a precise equivalent and decided to adapt this whole paragraph.

\subsection{Finding the right equivalent}

The notes added in the written translation include references to the specialised sources used in finding the right equivalent so that the language editor does not need to undertake another research process. These sources include specialised dictionaries, terminological databases, specialised sites on the Internet, and terminological bodies which offer a free consultation service.

For instance, in Red Storm many equivalents referring to wildlife such as "bilby"> "bilbi" or "spinifex hopping mouse"> "ratoli saltador del desert" are found in Cercaterm, a public terminological database. Sometimes personal consultations with Termcat (www.termcat.cat) solve the problem: this terminological body allows users to ask for specific terminology. This is what happened in the case of "ice-house effect": its Catalan equivalent ("efecte frigorific") was provided after terminologists working in this body consulted experts in the field. Specialised dictionaries are also used: for instance, in Crater of Death, the Catalan dictionary of Geology Diccionari de Geologia is used extensively.

\subsection{Absence of (or failure to find) an adequate equivalent}

Sometimes translators are not able to find an equivalent in the terminological sources and do not have enough time to undertake thorough research and consult specialists. In these instances they normally use different strategies, as shown next. It is frequently not evident whether the term was translated in this manner because the translator could not find an equivalent or simply because an equivalent does not exist.

\subsubsection{Creating new terms}


In the first instance, translators can create a new term. This is a perfectly valid approach as translators are trained to act as terminologists. However, a problem might arise if the term does not correspond with the one later proposed by terminological bodies. This was the case of "shocked quartz" in Crater of Death. The translator asked the terminological body Termcat for a Catalan equivalent but, as the reply took a few days —which is perfectly understandable - and the documentary had to be broadcast soon, a neologism was created: "quars fracturat" [fractured quartz]. When the official proposal was released - "quars d'impacte [impact quartz] —, it did not correspond with the translator's equivalent, but the documentary had already been recorded.

\subsubsection{Paraphrases}

Secondly, translators can use paraphrases to obviate the use of a term, as in (3) - from the same documentary-, where "wave beds" is explained by means of the descriptive paraphrase "beds formed by waves".

- Original version: Finding these thick deposits that may have been formed by giant waves in the deep sea was critical [...]. So by 1988 I was convinced that the impact had occurred somewhere within a thousand kilometres of the Caribbean, between North and South America.// Within a couple of years more wave beds were found around the western Caribbean.

- Catalan version: Era complicat trobar al fons del mar aquests dipòsits granats, formats possiblement per onades gegants [...]. Així, doncs, el mil nou-cents vuitanta-vuit, estava convençut que l'impacte s'havia produït en algun punt a mil quilòmetres del Carib, entre l'Amèrica del Nord i l'Amèrica del Sud. // Els dos anys següents es van trobar més llits formats per ones a la zona occidental del Carib. [It was critical to find in the deep sea these thick deposits, probably formed by giant waves [...]. So by 1988 I was convinced that the impact had occurred somewhere within a thousand kilometres of the Caribbean, between North and South America.// The next two years more beds formed by waves were found in the western Caribbean.]

\subsubsection{Loanwords}

Translators might decide to leave the term in the original language as a loanword, as in "überhackers" (Hackers), although sometimes this loanword is followed by an alternative denomination in the target language, as in (4) from The Quest. 
- Original version: Andrew and Ron will use rebreather tanks which recycle exhaled air, reducing bubbles. Rebreathers are more cumbersome to use but allow the divers to stay below without disturbing the whales.

- Catalan version: Andrew i Ron faran servir aparells de respiració pendular o rebreathers que reciclen l'aire expirat, cosa que redueix el nombre de bombolles. Aquests aparells són més incòmodes, però permeten que els bussos s'estiguin més temps sota l'aigua sense molestar les balenes. [Andrew and Ron will use pendular breathing devices or rebreathers which recycle exhaled air, which reduces the number of bubbles. These devices are more cumbersome, but allow the divers to stay below water without disturbing the whales.]

In a footnote the translator explains that in specialised publications found on the Internet the English equivalent seems to be commonplace and experts even use the abbreviation $R B$, although some other sites use "aparells de respiració pendular" [pendular breathing devices]. Since no official equivalent was found, and given the limited time, the translator decided to use both terms in the first instance and to use a hypernym in the second. This decision was made in 2005, but if doing the same translation today the translator would find an easier answer on the Cercaterm database, where the official proposal is "escafandre de circuit tancat" or "reciclador".

Sometimes, although leaving the term in the original language might seem a reasonable alternative, it might imply losing some metaphors, as in (5), from Hackers. In this case all the occurrences of three related terms — "black hats", "grey hats" and "white hats"had to be evaluated in context.

\section{Context 1}

- Original version: Some hackers defy the system. They call themselves black hats. They're $21^{\text {st }}$ century cowboys who will break the law to roam freely on the range of cyberspace.

- Catalan version: Hi ha hackers que desafien el sistema. Són els “black hats” o pirates informàtics. Són vaquers del segle vint-i-u que violen la llei per rondar lliurement pel ciberespai. [Some hackers defy the system. They are the black hats or crackers. They're $21^{\text {st }}$ century cowboys who will break the law to roam freely on the range of cyberspace.] 


\section{Context 2}

- Original version: Gradually, corporations are joining in, tempting hackers away from the dark side with big bucks to become 'white hats', hackers who use their outlaw skills to 'good' ends as IT consultants hacking to test security systems.

- Catalan version: De mica en mica, les empreses fan el mateix i tempten els hackers amb molts diners perquè deixin la cara fosca i es converteixin en white hats: hackers que fan servir la seva capacitat delictiva amb bons fins com a assessors de tecnologia de la informació que comproven la seguretat dels sistemes. [Gradually, corporations are doing the same and are tempting hackers away from the dark side with big bucks to become white hats, hackers who use their outlaw skills to good ends as IT consultants testing system security.]

\section{Context 3}

- Original version: There are different types of hackers, there's the white hat and the black hat. White hat hackers are the hackers who do things for a purpose, kind of the save-the-world type of hackers, secure this man-hole so no one falls into it type of thing. A lot of the black hat people won't talk about it, because black hat people are generally evil people, and they will hack websites, just to do it. I consider myself grey hat. Sometimes I like to pull the occasional prank.

- Catalan version: Hi ha diferents tipus de hackers: hi ha els white hat i els black hat. Els white hat són els que fan coses amb un motiu, volen salvar el món, tapen els forats perquè no hi caigui ningú. Molts dels pirates, els black hat, no en volen parlar perquè solen ser males persones que ataquen llocs web pel sol fet d'atacar-los. Jo em considero un entremig, un grey hat. De tant en tant m'agrada fer alguna brometa. [There are different types of hackers, there's the white hat and the black hat. White hat hackers are the hackers who do things for a purpose, want to save the world, secure man-holes so no one falls into it. A lot of the crackers, the black hat people, won't talk about it, because they are generally evil people who hack websites just to do it. I consider myself something in between, a grey hat. Sometimes I like to pull the occasional prank.]

As seen in the previous example, the text is self-explanatory and allows for no misunderstandings: "black hat" hackers are evil, "white hat" hackers are good, and "grey hat" hackers are a hybrid. These names come from western movies, where the villain would generally wear a black hat and the hero would wear a white one. This is why in context 1 the whole sentence is a metaphor and refers to cowboys who roam freely in the range of cyberspace. Unable to find a widely used equivalent which keeps the metaphor, the translator decided to adopt different strategies: in the first context, the English term is kept next to an equivalent which does not maintain the metaphor ("pirates informàtics" [crackers]). In the 
second context, the English term is also kept without any equivalence, but the context makes its meaning explicit. Finally, in the third context, different strategies are used: first of all, the two English terms "white hat" and "black hat" are left in the Catalan version, taking into account that a definition for both is provided next. In the case of "black hat" an equivalent is also included in once instance ("Molts dels pirates, els black hats"> [A lot of the crackers, the black hat people]) and is substituted by a pronoun in another part of the sentence ("black hat people are"> [(they) are $]$ ). As for "grey hat", the translator adds some information to make the meaning clearer to the audience: "I consider myself grey hat"> Jo em considero un entremig, un grey hat [I consider myself something in between, a grey hat].

\subsubsection{Language mechanisms: pre-fixation, analogy and blending}

Following the theoretical framework chosen, TU are lexical units from a linguistic perspective; hence, the same mechanisms used in general language words can be used to create new terms. For instance, pre-fixation processes were used to create undocumented TU such as "protodust"> "protopols" (Red Storm). Analogy was also used in creating terms such as "mantell de fosa" as an equivalent for "melt sheet". Although this term could not be found in terminological sources, other types of sheet with the same structure ("mantell d'alteració", "mantell d'escòries", "mantell de cendra") were included in dictionaries. Finally, a blend is also found in the corpus: "hacktivism", translated as "hacktivisme".

\subsection{Dealing with denominative variation}

A recurrent problem when translating documentaries is denominative variation, i.e. the occurrence of two or more equivalents in the target language, forcing the translator to make a decision, as to which one is the most appropriate term. In Freixa's words (2006:56) "denominative variation can be defined as the phenomenon in which one and the same concept has different denominations; this is not just a formal variation (variation between a term and a periphrasis, or a definition, for example), but is restricted to variation among different denominations, i.e. lexicalised forms, with a minimum of stability and consensus among the users of units in a specialised domain".

In (6), from Crater of Death, the translator looked up the term "debris" in a dictionary and found two denominations: "detritus" and "detrit". The main lemma — "detritus" — was chosen.

(6)

- Original version: This was not a wave bed. It was debris from the crater itself.

- Catalan version: Això no era un llit format per ones. Era detritus del cràter mateix. 
In another instance the translator explains in a footnote that the equivalent "cràter meteoric" [meteoric crater] was found in a specialised database. However, in a specialised dictionary a different form — "cràter meteorític" [meteoritic crater] - was listed next to "cràter d'impacte" [impact crater]. After asking the terminological bodies responsible for the database, it was found that the first form was a mistake and that either the second or the third ones should be used, as in (7).

(7)

- Original version: Tektites are globules of melt that are blasted out of impact craters.

- Catalan version: Les tectites són glòbuls de matèria fosa que surten dels cràters d'impacte. [Tektites are globules of melt that are blasted out of impact craters]

In (8), from The Quest, the translator found two possible equivalents for one term and decided to use both terms together in the translation, at least the first time they appeared in the documentary, to make it clear that both alternatives are valid and to enhance comprehension.

(8)

- Original version: Each year, on an isolated reef called Silver Bank, hundreds of humpback whales gather to breed.

- Catalan version: Cada any, en un escull aïllat anomenat banc de la Plata, centenars de balenes amb gep, o iubartes, es reuneixen per criar. [Each year, on an isolated reef called Silver Bank, hundreds of humpback whales gather to breed.]

An instance of the opposite was found in Red Storm (see 9): two forms in the source language were reduced to just one equivalent in the translation because no denominative variation existed in Catalan.

(9)

- Original version: The fierce snake or inland taipan was once thought extinct and was only recently rediscovered here in Diamantina country.

- Catalan version: El taipan ferotge es considerava extingit i no va ser fins fa poc que se'n van tornar a trobar al Diamantina. [The inland taipan was once thought extinct and was only recently rediscovered here in Diamantina] 


\section{6. "In vivo" vs. "in vitro" terminology}

Literature on terminology distinguishes between in vivo and in vitro terminology (Dubuc \& Lauriston 1997:87, Cabré 1999:80), with the former referring to terms used by experts, and the latter referring to units proposed by normalisation bodies which might not be accepted and used by either experts in the field or the general audience. When confronted with two possible equivalents -one in-vivo and another one in-vitro-, translators must ponder the consequence of their choices.

In Hackers even the title posed a problem for the translator: according to the official sources consulted at the time, the proposed equivalent for a "hacker" was "furoner" whilst "cracker" would be rendered by the term "pirata". Whilst the latter would be perfectly understood by the audience and was also widely used, the former ("furoner") was totally obscure and could even sound ridiculous. Taking into account all these issues - and taking into account the tone and abundance of colloquial language-, the translator decided to use the term "hacker", ignoring the official proposal. It must be noted that nowadays both proposals ("furoner" and "hacker") are officially accepted, probably due to the lack of implementation of the first form.

A different strategy was used in Red Storm. Three options were feasible when translating "smog": leaving the English term; using the official proposal "boirum", which is not the term commonly used by the general audience nor indeed by the experts, or using alternative descriptive paraphrases such as "boira contaminant" [polluting fog]. The second option was finally chosen, probably because the speaker in this particular context was a formal narrator and the translator found the proposal was worth supporting. It must not be forgotten that translators play a key role in implementing official proposals, so accepting or rejecting these proposed terms is a process with linguistic consequences.

\subsection{Mistranscriptions}

Translators sometimes work with a transcription of the audiovisual product. However, these transcriptions do sometimes contain mistakes and this can result in problems. For instance, in Hackers, recurrent incorrect transcriptions of the homophonous computer terms "route" and "root" were found. Another instance found is "medullamagada" instead of "medulla oblongata", referring to the brain stem. In these instances the translators had to be aware of the context in order to avoid the mistaken transcriptions and choose the adequate equivalent.

\section{Conclusions}


It is frequently said that audiovisual translators usually experience terminological problems when confronted with a documentary. This article has gone a step further and has demonstrated by means of a corpus analysis that terminology can cause a variety of problems in the translation of science documentaries. Some of the challenges found include identifying terms, understanding terms, finding the right equivalent, dealing with the absence or the inability to find an adequate equivalent, dealing with denominative variation, choosing between in vivo and in vitro terminology, and avoiding wrong transcriptions. Other publications (Matamala 2009b, 2009c) have outlined the other recurrent problems encountered in science documentaries: dealing with ambiguous terms, deciding whether to use or not obscure equivalents for a general audience, as well as disentangling the specificities of flora and fauna nomenclature.

As for the strategies used in solving terminological problems, this article has shown that adapting the translation, using a more general term and proposing an equivalent are used when the main problem is understanding the original. When the challenge is the absence of (or failure to find) an equivalent, paraphrasing the original, proposing a terminological neologism, using loanwords and creating terms using language resources are the most common mechanisms. It has been highlighted that some of the terminological neologisms created by translators do not coincide with TU later proposed by prescriptive bodies. Hence, it would be highly interesting to study if this is a recurrent problem and, if so, to find a mechanism to avoid duplication of efforts.

The analysis has also shown that the choice of a term in vivo or in vitro seems to depend on the speaker and on the particular context, but further research into this topic and into the acceptance/rejection of official proposals would also reveal interesting results.

A wider corpus selection including more topics and more languages would yield more accurate results but this paper should be considered a first step in the field of terminology and AVT. Needless to say, the constraints posed by the audiovisual nature of the product and, more specifically, by the transfer modes chosen (voice-over, off screen dubbing, subtitling) merit further investigation. In this sense, Matamala (2009c) presents the first analysis of this phenomenon and concludes that: firstly, TU sometimes refer to objects visible on the screen and the degree of referentiality is very high (Chaume 2003:195); hence, translators cannot choose omission as a translation strategy and they must synchronise the text with the image. Secondly, the ephemeral nature of audiovisual products —which must be understood immediately because the audience cannot stop and look up a term on a dictionary - compels translators to choose strategies which enhance comprehension (Espasa 2004:193). Thirdly, 
terms are received orally and this is why the script contains indications concerning the pronunciation of difficult terms addressed to the voice artists who read the script. Finally, audiovisual translators might have to work with erroneous transcriptions or even without a script. Therefore, understanding TU of a wide array of topics is an added challenge which is not faced by technical translators, for instance.

Apart from the specificities linked to the audiovisual nature of science documentaries, other follow-up investigations could deal with issues such as: comparing strategies in the translation of terminology in fiction and non-fiction films, analysing the translation of terminology in other types of documentaries, studying synchronisation strategies in voicedover documentaries and their effects in the translation of terminology, examining docudramas in order to discover if terminology is present and receives special treatment, and evaluating how the use of pivot translations - for instance, a translation into English of a Chinese documentary that has to be translated into Catalan - affects terminology, as proposed in Matamala (2009c). To sum it up, it is still a rather unexplored area of AVT studies which holds many future possibilities.

\section{References}

Arntz, R. 1993. Terminological equivalence and translation. In: Sonneveld, H. \& Loening, K. (eds.) Terminology. Applications in Interdisciplinary Communications. Amsterdam/Philadelphia: John Benjamins. 5-19.

Bestué, C. 2005. La traducció de la terminologia legal en la pel·lícula Saving Grace. Papers Lextra Vol 1. [Retrieved February $1^{\text {st }}$, 2009, from: http://www.lextra.uji.es/papers/2005/bestue05.htm.]

Cabré, M.T. 1992. La terminologia. La teoria, els mètodes, les aplicacions. Barcelona: Empúries.

Cabré, M.T. 1998. Las fuentes terminológicas para la traducción. In: Nistal, P. \& Bravo Gozalo, J.M. (coord.) La traducción: orientaciones lingüisticas y culturales. SAE: Universidad de Valladolid. 27-59.

Cabré, M.T.1999. La terminología: representación y comunicación. Barcelona: IULA.

Cabré, M.T. 2002. Análisis textual y terminología, factores de activación de la competencia cognitiva en la traducción. In: Alcina Caudet, A \& Gamero Pérez, S. (eds.) La traducción científico-técnica y la terminología en la sociedad de la información. Castelló de la Plana: Publicacions de la Universitat Jaume I. 87-106. 
Cabré, M.T. 2003. Theories of terminology. Their description, prescription and explanation. Terminology Vol. 9 No. 2. 163-200.

Cabré, M.T. 2004. La terminología en la traducción especializada. In: Gonzalo García, C. \& García Yebra, V. (eds.) Manual de documentación y terminología para la traducción especializada. Madrid: Arco/Libros. 89-125.

Cabré, M.T., Estopà, R., Freixa, J., Lorente, M. \& Tebé, C. 2002. Les necessitats terminològiques del traductor científic. In: Chabás, J.; Gaser, R. \& Rey, J. (eds.) Translating Science. Proceeding $2^{\text {nd }}$ International Conference on Specialised Translation. Barcelona: PPU. 165-174.

Chaume, F. 2003. Doblatge i subtitulació per a la TV. Vic: Eumo.

Célestin, T., Godbout, G. \& Vachon-L'Hereux, P. 1984. Méthodologie de la recherche terminologique ponctuelle: essai de définition. Quebec: Gouvernement du Québec.

Dubuc, R. \& Lauriston, A. 1997. Terms and contexts. In: Wright, S.E. \& Budin, G. (eds.) Handbook of Terminology Management. Amsterdam/Philadelphia: John Benjamins.

Espasa, E. 2004. Myths about documentary translation. In: Orero, P. (ed.) Topics on audiovisual translation. Amsterdam/Philadelphia: John Benjamins. 183-197

Cabré, M.T., Freixa, J., Lorente, M. \& Tebé, C. 2001. Textos de terminólogis de la Escuela Rusa. Barcelona: UPF, IULA.

Faceira, M.J. 2002. coord. A divulgaçao científica nos media. Avanca, Portugal: Ediçoes Cine-Clube de Avanca.

Felber, H. 1984. Terminology Manual. Vienna: Infoterm.

Ferreira, C. 2002. A legendagem de filmes de divulgação científica: crítica de tradução de um argumento. In Faceira, M.J. (coord.) A divulgação científica nos media. Avanca, Portugal: Cine-clube de Avanca. 105-121.

Franco, E. 2000a. Documentary film translation. A specific practice? In: Chesterman, A., Gallardo, N. \& Gambier, Y. (eds.) Translation in context. Amsterdam/Philadelphia: John Benjamins. 233-242.

Franco, E. 2000b. Revoicing the alien in documentaries. Cultural agency, norms and the translation of audiovisual reality. [Retrieved November $10^{\text {th }}$, 2008, from http://tede.ibict.br/tde_arquivos/1/TDE-2005-02-23T06:09:47Z-

94/Publico/ElianaPCFranco.pdf.]

Franco, E. 2001a. Inevitable exoticism: The translation of culture-specific items in documentaries. In: Chaume, F. \& Agost, R. (eds.) La traducción en los medios audiovisuales. Castelló de la Plana: Publicacions de la Universitat Jaume I. 177-181. 
Franco, E. 2001b. Voiced-over television documentaries. Terminological and conceptual issues for their research. Target Vol. 13. No. 2. 289-304.

Franco, E., Matamala, A. \& Orero, P. Forthcoming. Voice-over Translation: A Guidebook. Frankfurt: Peter Lang.

Freixa, J. 2005. Variación terminológica: ¿Por qué y para qué? Meta Vol. 50. No. 4. [Retrieved October 25th, 2009, from http://id.erudit.org/iderudit/019917ar.]

Freixa, J. 2006. Causes of denominative variation in terminology: A typology proposal. Terminology Vol. 12. No 1. 51-77. [Retrieved October 25th, 2009, from http://www.benjamins.nl/jbp/series/TERM/12-1/art/04fre.pdf]

Gaudin, F. 2003. Socioterminologie. Une approche sociolinguistique de la terminologie. Brussels: Duculot De Boeck.

Gouadec, D.; Toudic, D. (eds.) 2003. Traduction, terminologie, rédaction. Paris: La Maison du Dictionnaire.

Hoorickx-Raucq, I. 2004. Mediating the scientific text. A cultural approach to the discourse of science in some English and French publications and TV documentaries. Jostrans Vol. 3. 97-108.

Kaufmann, F. 2004. Un exemple d'effet pervers de l'uniformisation linguistique dans la traduction d'un documentaire: de l'hébreu des immigrants de "Saint-Jean" au français normatif d'ARTE. Meta Vol. 49. No. 1. 148-160.

Kaufmann, F. 2008. Le sous-titrage des documentaires: défis et enjeux de l'établissement du texte de départ. In: Serban, A. \& Lavaur, J.M. (eds.) La traduction audiovisuelle. Approche interdisciplinaire du sous-titrage. Brussels: De Boeck. 69-83.

León, B. 1999. El documental de divulgación científica. Barcelona: Paidós. [English translation: León, B. 2007. Science on Television. The Narrative of Scientific Documentary. Luton: Pantaneto Press.]

Lozano, D. 2008. Aproximación a la traducción de la terminología médica de series dobladas al español: el caso de "Urgencias". Unpublished MA dissertation. Bellaterra, Spain: Universitat Autònoma de Barcelona.

Lozano, D.; Matamala, A. 2009. The translation of medical terminology in TV fiction series. VIAL. Vigo International Journal of Linguistics Vol 6. 73-88.

Matamala, A. 2009a. Translating documentaries: from Neanderthals to the Supernanny. Perspectives. Studies in Translatology Vol 17. No 2. 93-107.

Matamala, A. 2009b. Main challenges in the translation of documentaries. In Díaz-Cintas, J. (ed.) In So Many Words: Translating for the Screen. London: Multilingual Matters. 112-126. 
Matamala, A. 2009c. La traducción de la terminologia en documentals de divulgació científica". Research project presented on October $16^{\text {th }} 2009$ at the open competition for tenure. Bellaterra: UAB. Unpublished manuscript.

Mateu, J. 2005. La innovació en la traducció de documentals. Quaderns divulgatius Vol. 26. [Retrieved November 9th, 2008, from http://www.escriptors.cat/pagina.php?id_text=992.]

Mir, J. 1999. Documentaries: problems and solutions. Quaderns divulgatius Vol. 12. [Retrieved November 9th, 2008, from http://www.escriptors.cat/pagina.php?id text=326]

Nichols, B. 2001. Introduction to Documentary. Bloomington: Indiana University Press.

Orero, P. 2004. The pretended easiness of voice-over translation of TV. Jostrans Vol. 2. 7696.

Orero, P. 2005. La traducción de entrevistas para voice-over. In: Zabalbeascoa, P.; Santamaria, L. \& Chaume, F. (eds.) La traducción audiovisual: investigación, enseñanza y profesión. Granada: Comares. 213-222.

Orero, P. 2006. Synchronization in voice-over. In: Bravo, J.M. (ed.) A new spectrum of translation studies. Valladolid: Publicaciones de la Universidad de Valladolid. 255-264.

Orero, P. 2007. Voice-over: A case of hyper-reality. MuTra 2006-Audiovisual Translation Scenarios: Conference Proceedings. [Retrieved November 9th, 2008, from http://www.euroconferences.info/proceedings/2006_Proceedings/2006_Orero_Pilar.pdf.] Rabiger, M. 2004. Directing the Documentary. Oxford: Elsevier.

Remael, A. 1995-1996. From the BBC's Voices from the Island to the BRTN's De President van Robbeneiland. A Case Study in TV Translation. Linguistica Antverpiensia Vol. XXIXXXX. 107-128.

Remael, A. 2007. Whose language, whose voice, whose message? Different AVT modes for documentaries on VRT-Canvas Television, Flanders. TradTerm Vol. 13. 31-50.

Renov, M. 1993. Theorizing Documentary. New York: Routledge.

Rogers. M. 2006. How do specialist translators research their terminology? A case study approach with a historical perspective. In: Gotti, M. \& Sarcevic, S. (eds.) Insights into specialised translation. Bern: Peter Lang. 329-345.

Sager, J-C. 1992. The translator as terminologist. In: Dollerup, C.; Loddegaard, A. (ed.) Teaching Translation and Interpreting Training, Talent and Experience. Amsterdam: John Benjamins, 107-122.

Taylor, C. 2002. The Subtitling of Documentary Films. Rassegna Italiana di Linguistica Aplicata. Vol. 34. No.1-2. 143-160. 
Temmerman, R. 2000. Towards New Ways of Terminology Description. The Sociocognitive Approach. Amsterdam/Philadelphia: John Benjamins.

Velasquez, G. 2002. La traducción y la terminología en la comunicación bilingüe mediada. Meta Vol. 47. No. 3. 444-459.

Wüster, E. 1979. Einführung in die Allgemeine Terminologielehre und Terminologische Lexikographie. Viena: Springer. 